\title{
A methodology for creating greenways through multidisciplinary sustainable landscape planning
}

\author{
Selma Beatriz Pena ${ }^{\mathrm{a}, *}$, Maria Manuela Abreu ${ }^{\mathrm{b}}$, Rui Teles ${ }^{\mathrm{c}}$, Maria Dalila Espírito-Santo ${ }^{\mathrm{d}}$ \\ ${ }^{a}$ Centro de Estudos de Arquitectura Paisagista Prof. Caldeira Cabral, Instituto Superior de Agronomia, Universidade Técnica de Lisboa (TULisbon), Tapada da Ajuda, \\ 1349-017 Lisbon, Portugal \\ ${ }^{\mathrm{b}}$ Unidade de Investigação de Química Ambiental, Instituto Superior de Agronomia, Universidade Técnica de Lisboa (TULisbon), Tapada da Ajuda, 1349-017 Lisbon, Portugal

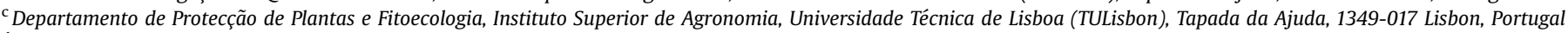

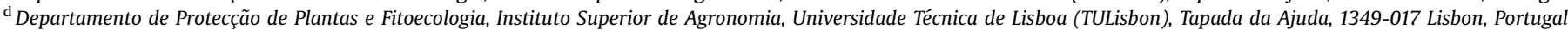

\section{A R T I C L E I N F O}

\section{Article history:}

Received 14 August 2008

Received in revised form

14 October 2009

Accepted 5 December 2009

Available online 28 December 2009

\section{Keywords:}

Landscape system

Rural greenway planning

Green corridors

Greenway design

Lisbon metropolitan area (Portugal)

\begin{abstract}
A B S T R A C T
This research proposes a methodology for defining greenways via sustainable planning. This approach includes the analysis and discussion of culture and natural processes that occur in the landscape. The proposed methodology is structured in three phases: eco-cultural analysis; synthesis and diagnosis; and proposal.

An interdisciplinary approach provides an assessment of the relationships between landscape structure and landscape dynamics, which are essential to any landscape management or land use. The landscape eco-cultural analysis provides a biophysical, dynamic (geomorphologic rate), vegetation (habitats from directive 92/43/EEC) and cultural characterisation. The knowledge obtained by this analysis then supports the definition of priority actions to stabilise the landscape and the management measures for the habitats. After the analysis and diagnosis phases, a proposal for the development of sustainable greenways can be achieved.

This methodology was applied to a study area of the Azambuja Municipality in the Lisbon Metropolitan Area (Portugal). The application of the proposed methodology to the study area shows that landscape stability is crucial for greenway users in order to appreciate the landscape and its natural and cultural elements in a sustainable and healthy way, both by cycling or by foot. A balanced landscape will increase the value of greenways and in return, they can develop socio-economic activities with benefits for rural communities.
\end{abstract}

(c) 2009 Elsevier Ltd. All rights reserved.

\section{Introduction}

Since prehistoric times, mankind has had an interactive and empirical relationship with landscape (Telles, 1992). People lived on high ground for protection whilst they cultivated the lower fertile valleys and used the products of nature to survive. This past knowledge and wisdom, which can be considered balanced and sustainable, has been lost or ignored over recent decades. In contrast, many of mankind's later actions have had negative effects on landscape. How then can mankind use landscape without damaging and compromising its natural regenerative capacity? The answer lies in the understanding and interpretation of the natural and cultural processes of Landscape, on the Landscape Structures.

\footnotetext{
* Corresponding author. Tel.: +351 2136533 14; fax: +351 213653432 .

E-mail addresses: selmapena@isa.utl.pt (S.B. Pena), manuelaabreu@isa.utl.pt (M.M. Abreu), ruiteles@isa.utl.pt (R. Teles), dalilaesanto@isa.utl.pt (M.D. Espírito-Santo).
}

That knowledge should then be applied to planning the landscape and used to influence decision-makers. This approach leads to sustainable landscape planning.

The concept of landscape that is used is the result of the interaction between natural and cultural processes (Goodchild, 2002). This concept is also reflected in the European Landscape Convention, where it is defined as the result of the action and interaction of natural and/or human factors (Council of Europe, 2000). Hence, man is one of the interactive 'pieces' of the landscape system.

Chadwick (1978) defines a system as a complex of elements standing in interaction. Landscape is also a complex system. The conceptualisation and spatial representation of relations between those elements was developed by Magalhães et al. (2003, 2007). The natural and cultural dimensions were integrated through an ecological and cultural structure. The ecological structure is made up of the natural elements that are part of the fundamental ecological systems. The ecological structure is also a juridical tool of territorial management, according to Portuguese legislation (Decree-Law no. 


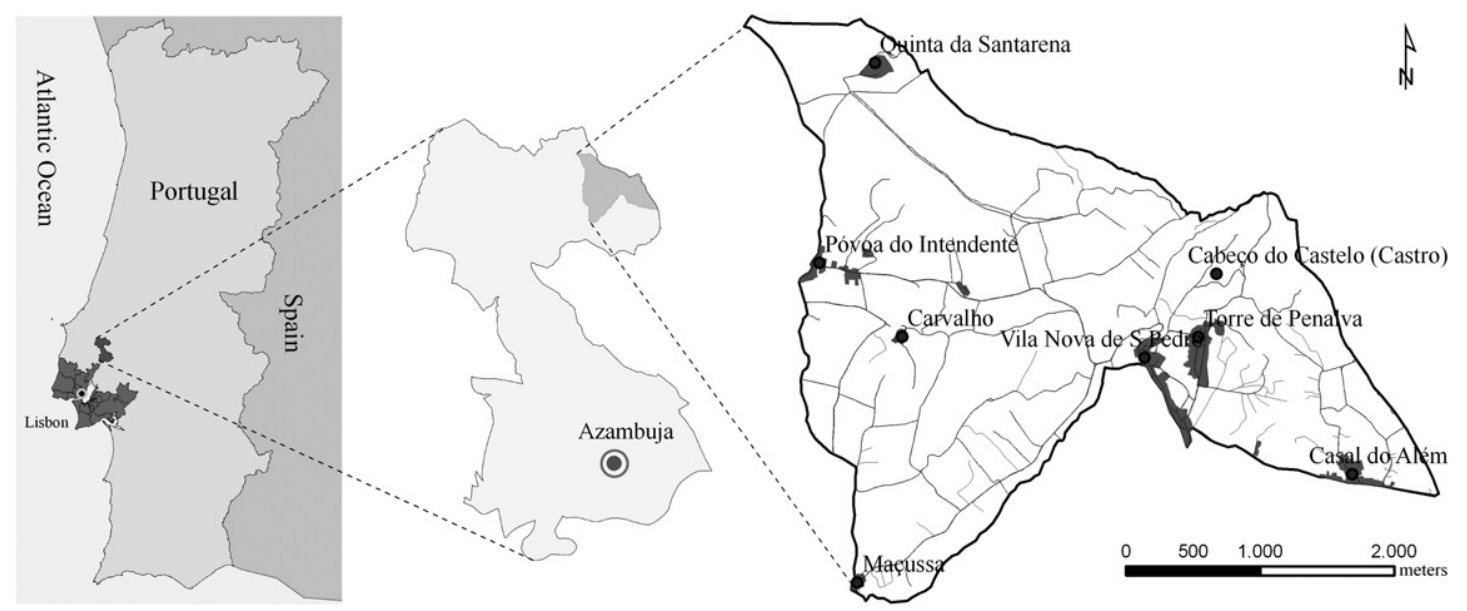

Fig. 1. Location of the study area in Portugal, Lisbon Metropolitan area (in black) and Azambuja Municipality.

380/99). The main urban and rural elements, those that leave marks on landscape, make up the cultural structure (roads, compartments of rural landscape, Portuguese farms - productive and recreational farms, traditional villages, religious or industrial buildings, etc.). As part of the collective memory, these elements are the cultural identity of a place and should be considered in planning and management decisions (Stephenson, 2008).

Within this integrated perspective, landscape is a living ecological organism (Sauer, 1925) that consists of interactive physical and biotic components in which human beings interact and transform landscape (Magalhães, 2001). Therefore, whenever there is landscape planning or intervention, it is crucial to study landscape as a dynamic system. In order to undertake a thorough ecological analysis of the landscape, it is essential that the complexity of its components be considered (Christofoletti, 1999).

The structures that comprise the complex ecological system are geology, climate, geomorphology, soil, vegetation and fauna. Time, as a transverse variable, must also be considered. After the analysis of the natural system, it is important to understand the cultural systems and the complexity of the interrelationships between natural and cultural processes. This analysis should be made in a holistic way, where the system is more than the sum of its components (Korhonen, 2007). According to McHarg (1971), the first author to advocate a holistic view of the landscape in terms of design: "Man's life, in sickness and in health, is bound up with the forces of nature, and that nature, so far from being opposed and conquered, must be treated as a friend, whose ways must be understood, and whose council must be respected". Understanding the natural and cultural interrelationships constitutes the first step towards achieving landscape sustainability. The comprehension of environmental sensitivity can give way to sustainable development ((Cloquell-Ballester et al., 2008) by supporting decisions regarding interventions from ecological, economic and social perspectives.

Landscape sustainability can be achieved by ecological landscape planning which brings together the interactions of both the natural and cultural landscape structures. Landscape ecological planning was previously defined by Ahern (2005) as a "specialization within landscape planning that focuses on spatial planning, the organization of uses and relationships of land uses to achieve explicit goals (e.g. sustainability)". The same author also considers that "sustainable planning aspires to link knowledge about sustainability with actions to achieve it" (Ahern, 2005). Some of the actions that can improve landscape sustainability are the greenways and nature tourism.

Greenways are networks of linear elements that are planned, designed and managed for multiple purposes, including ecological, recreational, cultural, aesthetic or other purposes compatible with the concept of sustainable land use (Ahern, 1995).

Nature Tourism, Ecotourism and Rural Tourism are all forms of tourism that value the economic aspect, as well as the protection and importance of natural resources. These types of tourism centre on natural, historical and cultural heritage, as well as the participation of local populations. However, some differences can be considered between them. For example, nature tourism is tourism in areas that promotes the understanding of the environment, appreciation of the culture and lifestyle of the local population

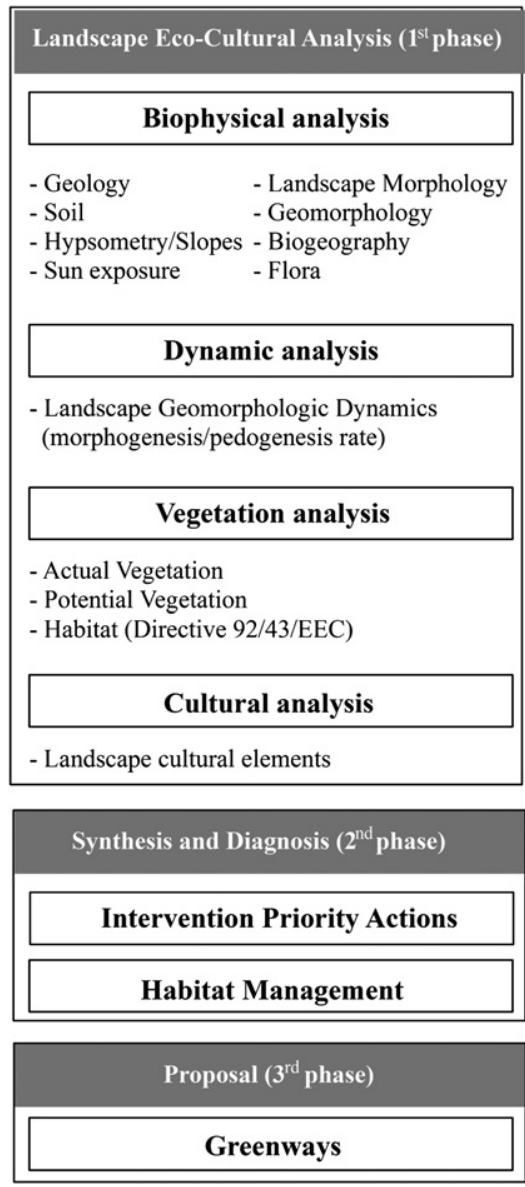

Fig. 2. Synthesis of the proposed methodology. 
Table 1

Priority Intervention actions according to the geomorphologic landscape dynamic and slope value. Synthesis of diagnose, action and main objective foe each class.

\begin{tabular}{|c|c|c|c|c|c|c|}
\hline Class & $\begin{array}{l}\text { Geomorphologic } \\
\text { landscape dynamic }\end{array}$ & $\begin{array}{l}\text { Slope } \\
\text { Value (\%) }\end{array}$ & Priority & Diagnose & Action & $\begin{array}{l}\text { Main } \\
\text { objective }\end{array}$ \\
\hline I & $\begin{array}{l}\text { Morphogenesis } \\
\text { Intergrade to } \\
\text { morphogenesis }\end{array}$ & $\begin{array}{l}>16 \\
12-16 \\
<12\end{array}$ & Maximum & $\begin{array}{l}\text { High susceptibility } \\
\text { to erosion processes }\end{array}$ & $\begin{array}{l}\text { Urgent intervention } \\
\text { to achieve soil genesis } \\
\text { or conservation } \\
\text { Vegetation development }\end{array}$ & Land use change \\
\hline II & $\begin{array}{l}\text { Intergrade to } \\
\text { pedogenesis }\end{array}$ & $\begin{aligned}> & 16 \\
& 12-16 \\
< & 12\end{aligned}$ & Medium & $\begin{array}{l}\text { Present some } \\
\text { stabilization }\end{array}$ & $\begin{array}{l}\text { Recovery measures and } \\
\text { conservation according } \\
\text { to slope value }\end{array}$ & Recovery \\
\hline III & Pedogenesis & $0-3$ & Minimum & $\begin{array}{l}\text { Geomorphologic } \\
\text { stability }\end{array}$ & Conservation measures & Conservation \\
\hline
\end{tabular}

A

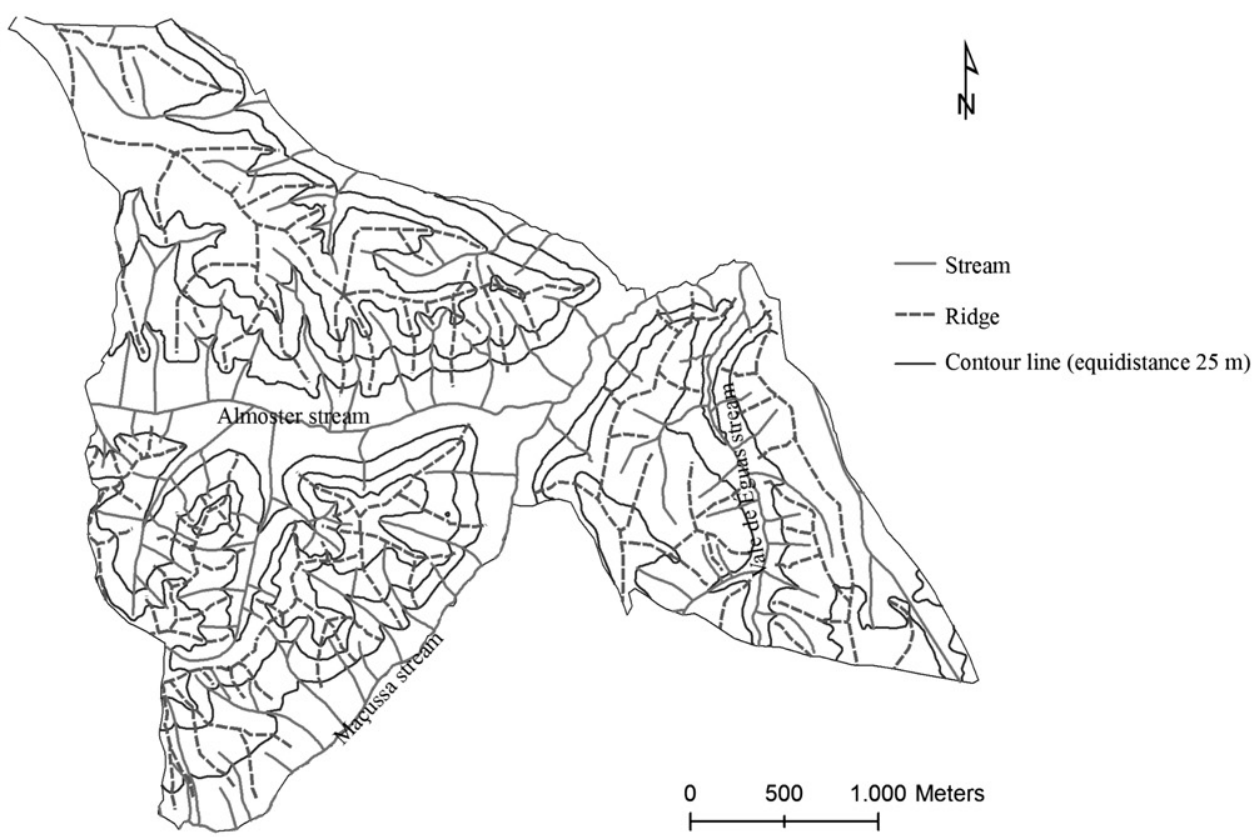

B

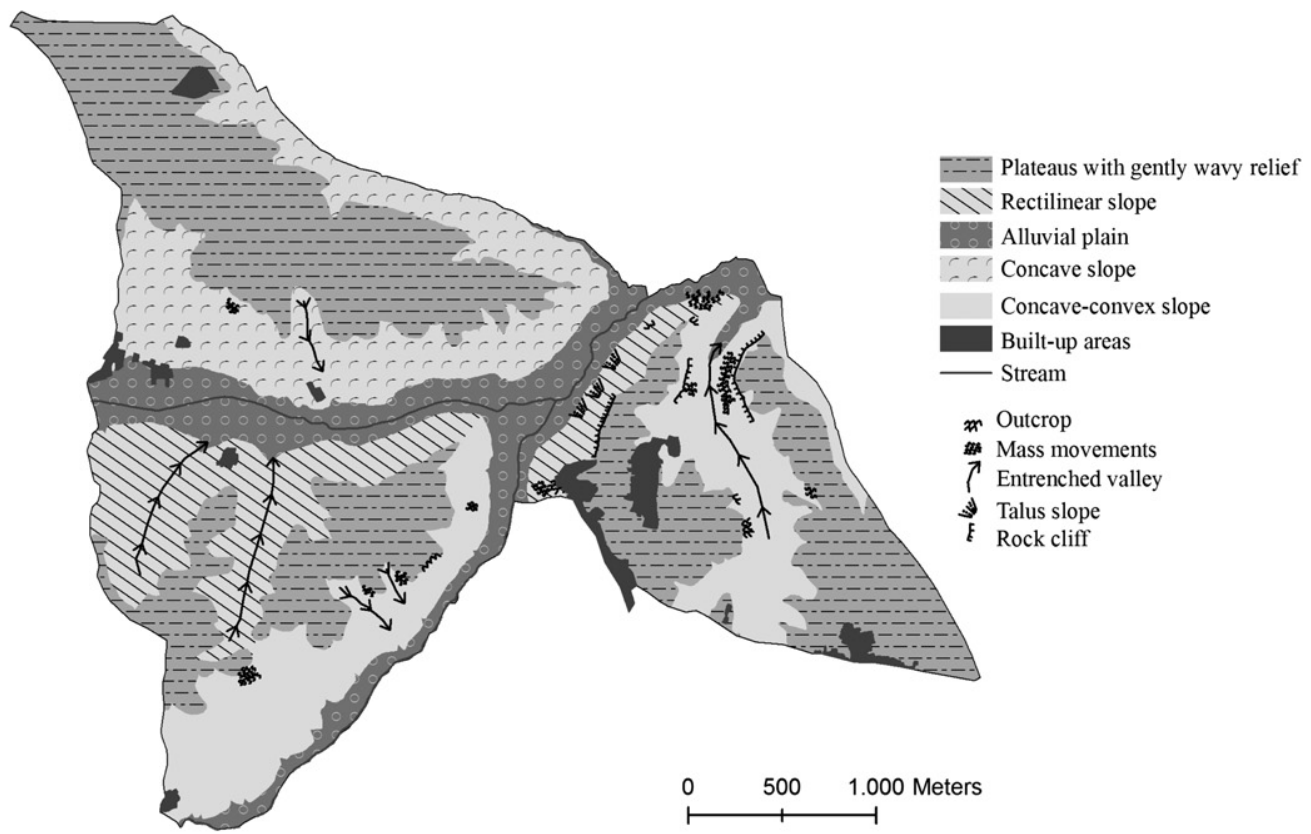

Fig. 3. Eco-cultural analysis phase (biophysical analysis): A - physiography map; B - geomorphology map. 


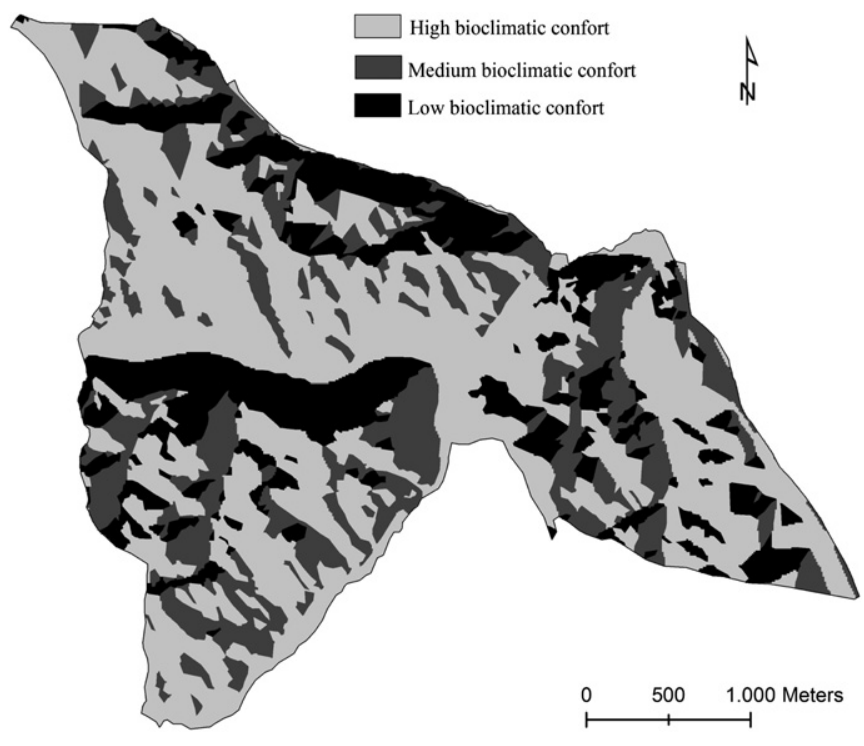

Fig. 4. Eco-cultural analysis phase (biophysical analysis): bioclimatic confort.

(Young, 1992). The International Ecotourism Society defined ecotourism as responsible travel to natural areas that conserves the environment and improves the well-being of local people. Environmental education is also a way to promote and make the population more aware of issues of sustainability, nature and culture. The use of bicycles, associated with bicycle touring, is an increasingly important vacation type (Ritchie, 1998) and it also has an important effect on the promotion of environmental benefits and health benefits for the user (Parkin et al., 2007).

In sustainable landscape planning and tourism, roads have environmental disadvantages but also are necessary for economic survival and management. Building and maintaining roads has become controversial because of public concerns about their short and long-term effects on the environment and the value that society now places on road-free countryside (Cole and Landres, 1996; Williams, 1998). Traditionally, the planning of a rural road network is based on economic and social considerations. In recent years, traffic

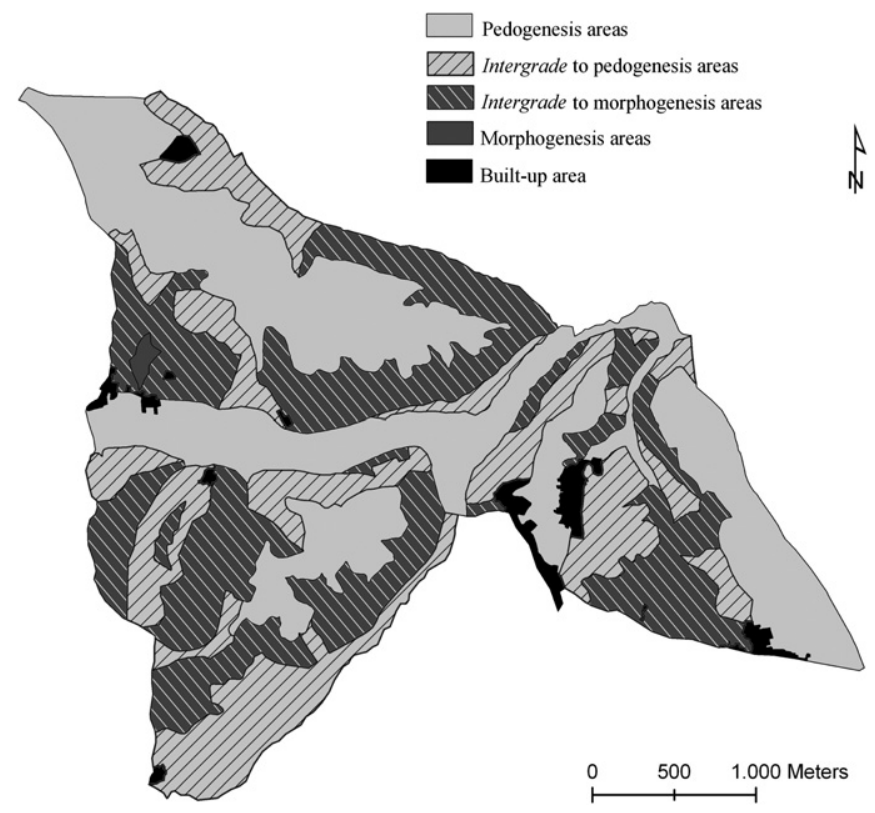

Fig. 5. Eco-cultural analysis phase (dynamic analysis): landscape geomorphologic dynamics map.
Table 2

Landscape Geomorphologic Dynamics of the study site (area, percentage and main characteristics).

\begin{tabular}{|c|c|c|c|}
\hline $\begin{array}{l}\text { Landscape } \\
\text { Geomorphologic } \\
\text { Dynamics }\end{array}$ & $\begin{array}{l}\text { Area } \\
\text { (ha) }\end{array}$ & $\begin{array}{l}\text { Percentage } \\
\text { of the total } \\
\text { area of } \\
\text { Intervention }\end{array}$ & Main characteristics \\
\hline Pedogenesis & 409.60 & 39.8 & Well compartment landscapes \\
\hline $\begin{array}{l}\text { Areas in Intergrade } \\
\text { to Pedogenesis }\end{array}$ & 265.00 & 25.7 & $\begin{array}{l}\text { No signs of degradation } \\
\text { Stabilization by vegetation }\end{array}$ \\
\hline $\begin{array}{l}\text { Areas in Intergrade } \\
\text { to Morphogenesis }\end{array}$ & 326.50 & 31.7 & $\begin{array}{l}\text { Soil erosion } \\
\text { Mass movements }\end{array}$ \\
\hline Morphogenesis & 3.10 & 0.3 & $\begin{array}{l}\text { Steep slopes } \\
\text { Lack of vegetation cover } \\
\text { Incorrect agricultural practices } \\
\text { Decapitation of soil profile }\end{array}$ \\
\hline Built-up areas & 25.70 & 2.5 & - \\
\hline
\end{tabular}

volume has shown considerable growth, despite an extension of road networks. Meanwhile, some harmful effects of these networks and their traffic flows have become more visible. The dangers of traffic, emissions and noise affect local people, flora and fauna (Jaarsma, 1994, 1997; Jaarsma and van Langevelde, 1996). In rural areas, roads are often crucial for management purposes, for example forest management, regardless of their main connectivity objectives. Environmental maintenance, wood harvesting, game control, recreational activities - all require the accessibility provided by a suitable road network (Demir and Hasdemir, 2005; Demir, 2007).

The aim of this work is to propose a methodology for defining greenways that can bring together the cultural and natural processes of the landscape to finally attain sustainable planning with it associated ecological, social and economic implications. The methodology is used to create a greenway system in part of the outer lying metropolitan area of Lisbon.

The methodology proposed here recognizes landscape as a complex and dynamic system with interactive natural and cultural elements. This analysis is accomplished through the assessment of the landscape main sub-system: geology, climate, geomorphology, soil, vegetation and man. Some of the existing methods to propose greenways (Toccolini et al., 2006) have some limitations to integrate many aspects of landscape elements for sustainable landscape planning and management.

The structure of this paper is as follows: After developing and characterising the proposed methodology and its phases, it is then applied to an area within the Lisbon Metropolitan Area. Subsequently, the advantages and weaknesses of the methodology are discussed and the main conclusions summarised.

\section{Materials and methods}

\subsection{Study area}

The study site at Almoster lies within an area of the Azambuja Municipality (Longitude: $8^{\circ} 51^{\prime} \mathrm{W}$, Latitude: $39^{\circ} 12^{\prime} \mathrm{N}$ ), which belongs to the Lisbon Metropolitan Area of Portugal (Fig. 1). Despite being in a metropolitan area, the Almoster study area has rural landscape characteristics, such as small villages and cultivated fields. The study area has an altitude between 20 and $120 \mathrm{~m}$ AOD. The study site measures 1030 ha and the main villages are: Vila Nova de S. Pedro, Torre de Penalva, Casal do Além and Póvoa do Intendente.

\subsection{Methodology}

The proposed methodology for the design of greenways was developed in three phases (Fig. 2), namely: landscape eco-cultural analysis, synthesis and diagnosis, and proposal. 
A

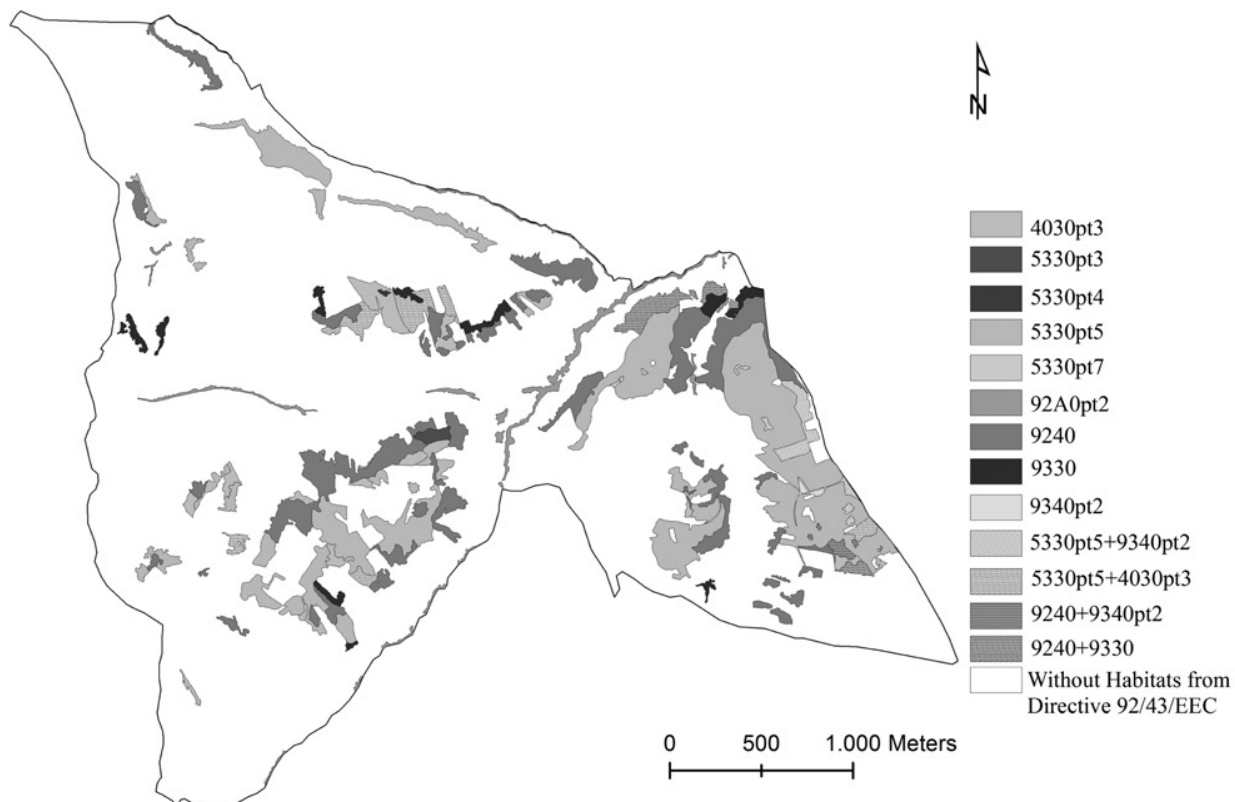

4030pt3 - European heaths; 5330pt3 - Arbutus unedo Thermo-Mediterranean and pre-desert scrub; 5330pt4 - Quercus lusitanica Thermo-Mediterranean and pre-desert scrub; 5330pt5 - Quercus coccifera Thermo-Mediterranean and re-desert scrub; 5330pt7 - Thymus sylvestris Thermo-Mediterranean and re-desert scrub; 92A0pt2 - Mediterranean deciduous forests - Salix alba and Populus alba galleries; 9240 - Mediterranean deciduous forests Q.faginea subsp. broteroi Iberean woods; 9330 - Mediterranean clerophyllous forests - Q.suber forests; $9340 \mathrm{pt} 2$ - Mediterranean scleroplyllous forests

B

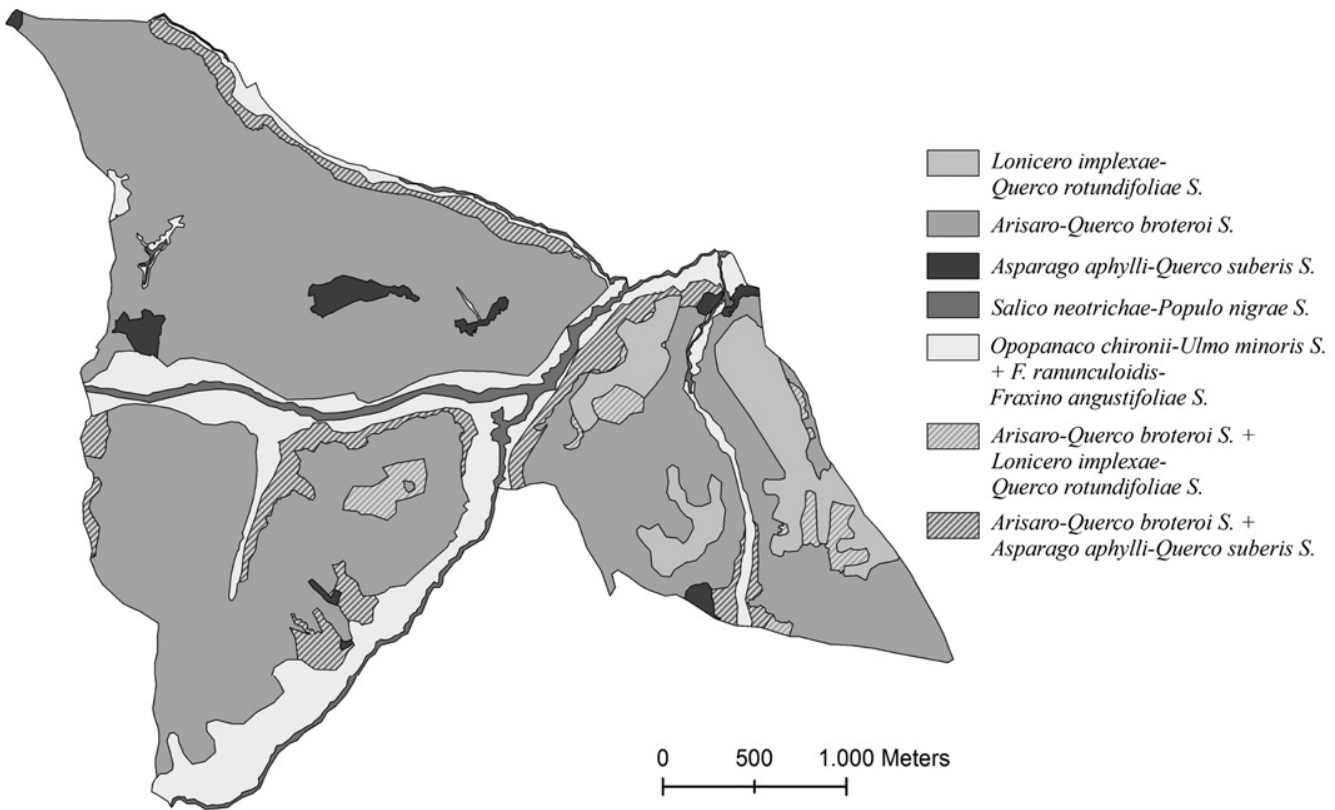

Fig. 6. Eco-cultural analysis phase (vegetation analysis): A - habitats from Directive 92/43/EEC map; B - potential vegetation map.

The landscape eco-cultural analysis and the study of its different components (biophysical, geomorphologic dynamics, vegetation, and cultural analyses) were accomplished through the gathering and interpretation of field data previously collected by the authors, and complemented with published documents and cartography. The data were developed using Geographic Information System (GIS) software.

The analysis of the biophysical component included the study of geology, soils, hypsometry, slopes, landscape morphology, geomorphology, sun exposure, bioclimatology, biogeography and flora. This phase of the methodology offered a first perception of the ecological characteristics of the surveyed area. The base maps used were geological, 1:50,000 scale, (Zbyszewski, 1953 and
Zbyszewski et al., 1966), soil, 1:25,000 scale, (IHERA, 1970), topographical, 1:25,000 scale, and bioclimatic (Rivas-Martínez, 2005) cartography. The other cartography used for this work was produced by the authors. Aerial photography with a resolution of $0.05 \mathrm{~m}$ was also used. It also provided insight into the origin of the landscape morphology and the biophysical limitations and potentials in terms of planning.

The analysis of the geomorphologic dynamics was carried out through the morphogenesis/pedogenesis rate, which led to an understanding of the landscape dynamics and consequently its degree of stability or instability. This rate characterises the landscape as pedogenesis, morphogenesis, intergrade to pedogenesis or intergrade to morphogenesis states (Tricart, 1965, 1994) and it was 
Table 3

Serial vegetation of the study area and identified habitats code (Directive 92/43/EEC).

\begin{tabular}{|c|c|c|c|}
\hline & & $\leftarrow$ Soil $\mathrm{pH}^{\mathrm{a}} \leftarrow$ & \\
\hline & & $\leftarrow$ Soil moisture $\leftarrow$ & \\
\hline Succession & $\begin{array}{l}\text { Asparago aphyllii- } \\
\text { Querco suberis S } \\
\text { (cork oak succession) }\end{array}$ & $\begin{array}{l}\text { Arisaro-Querco broteroi S. } \\
\text { (portuguese oak succession) }\end{array}$ & $\begin{array}{l}\text { Lonicero implexae-Querco } \\
\text { rotundifoliae S. (holm oak succession) }\end{array}$ \\
\hline Woodland & $\begin{array}{l}\text { Asparago aphylli- } \\
\text { Quercetum suberis (9330) }\end{array}$ & $\begin{array}{l}\text { Arisaro clusi- } \\
\text { Quercetum broteroi (9240) }\end{array}$ & $\begin{array}{l}\text { Lonicero implexae-Quercetum } \\
\text { rotundifoliae (9340pt2) }\end{array}$ \\
\hline$\downarrow$ & $\downarrow$ & $\downarrow$ & $\downarrow$ \\
\hline Chaparral & $\begin{array}{l}\text { Phillyreo angustifoliae- } \\
\text { Arbutetum unedonis (5330pt3) }\end{array}$ & $\begin{array}{l}\text { Melico arrectae-Quercetum } \\
\text { cocciferae (habitat 5330pt5) } \\
\text { Bupleuro fruticosae- } \\
\text { Arbutetum unedonis } \\
\text { (5330pt3) }\end{array}$ & $\begin{array}{l}\text { Quercetum cocciferae-airensis } \\
\text { (5330pt5) }\end{array}$ \\
\hline$\downarrow$ & $\downarrow$ & $\downarrow$ & $\downarrow$ \\
\hline $\begin{array}{l}\text { Perrenial } \\
\text { grassland }\end{array}$ & $\begin{array}{l}\text { Phlomido lychnitidis- } \\
\text { Brachypodietum } \\
\text { phoenicoidis (6210) }\end{array}$ & $\begin{array}{l}\text { Phlomido lychnitidis- } \\
\text { Brachypodietum } \\
\text { phoenicoidis (6210) }\end{array}$ & $\begin{array}{l}\text { Carici depressae/Hyparrhenietum } \\
\text { sinaicae }\end{array}$ \\
\hline$\downarrow$ & $\downarrow$ & $\downarrow$ & $\downarrow$ \\
\hline $\begin{array}{l}\text { Low- } \\
\text { Scrubland }\end{array}$ & $\begin{array}{l}\text { Erico-Quercetum } \\
\text { lusitanicae (5330pt4) }\end{array}$ & $\begin{array}{l}\text { Ulici airensis-Ericetum } \\
\text { scopariae (4030pt3) }\end{array}$ & $\begin{array}{l}\text { Teucrio capitatae-Thymetum sylvestris (5330pt7) } \\
\text { Ulici airensis-Ericetum scopariae }(4030 \mathrm{pt} 3)\end{array}$ \\
\hline $\begin{array}{l}\downarrow \\
\text { Annual } \\
\quad \text { Grasland }\end{array}$ & $\begin{array}{l}\downarrow \\
\text { Trifolio cherleri- } \\
\text { Plantaginetum bellardii }\end{array}$ & $\begin{array}{l}\downarrow \\
\text { Velezio rigidae-Asteriscetum } \\
\text { aquaticae }\end{array}$ & $\downarrow$ \\
\hline $\begin{array}{l}\text { Edge of } \\
\text { woodland }\end{array}$ & $\begin{array}{l}\text { Phyllreo angustifoliae- } \\
\text { Arbutetum unedonis (5330pt3) }\end{array}$ & $\begin{array}{l}\text { Lonicero hispanicae-Rubetum } \\
\text { ulmifolii prunetosum insititioidis } \\
\text { /Leucanthemo sylvatici-Cheirolophetum } \\
\text { sempervirentis }\end{array}$ & Quercetum cocciferae-airensis (5330pt5) \\
\hline
\end{tabular}

a The arrows denotes the intensification direction of $\mathrm{pH}$ and moisture.

evaluated qualitatively by cartography analysis and field work. The pedogenesis concept involves all processes that lead to soil formation and, consequently, by means of vegetation, to biomass production, energy conservation and $\mathrm{CO}_{2}$ sequestration. In contrast, morphogenesis is a result of erosion processes leading to soil loss, decrease of soil formation and insufficient vegetation growth. These processes are energy wasting and result in the actual landscape destruction. The intergrade landscape state between pedogenesis and morphogenesis represents an intermediate stage in which the landscape dynamic approaches stability or instability, respectively. This analysis was carried out with data collected from the observation and interpretation of landscape by field work using geological and topographic information (contained in specific published cartography) as well as aerial photography. In the field work, erosion factors, rock weathering, vegetation cover density, soil depth and agricultural practices were evaluated. After data collection, they were integrated into a Geographic Information System that synthesized the morphogenesis/pedogenesis rate.

Vegetation analysis was accomplished by a phytosociological approach (Braun-Blanquet, 1979). This methodology studies plant communities and their relationships with the environment and their dynamics. It also studies the natural processes by which certain plant communities or vegetation stages replace each other in particular order within the same unit or tesela (landscape unity). The vegetation analysis included 78 in situ surveys carried out between March and August 2005, during which 291 taxa divided

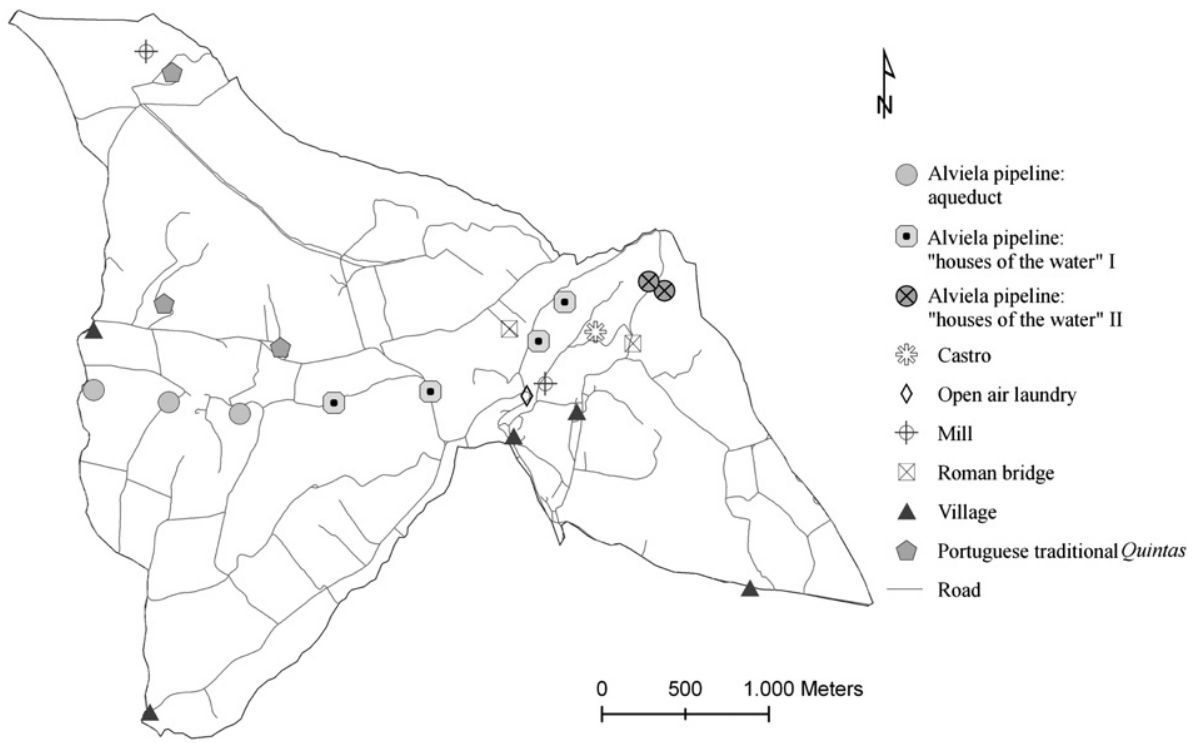

Fig. 7. Eco-cultural analysis phase (cultural analysis): cultural patrimony map. 

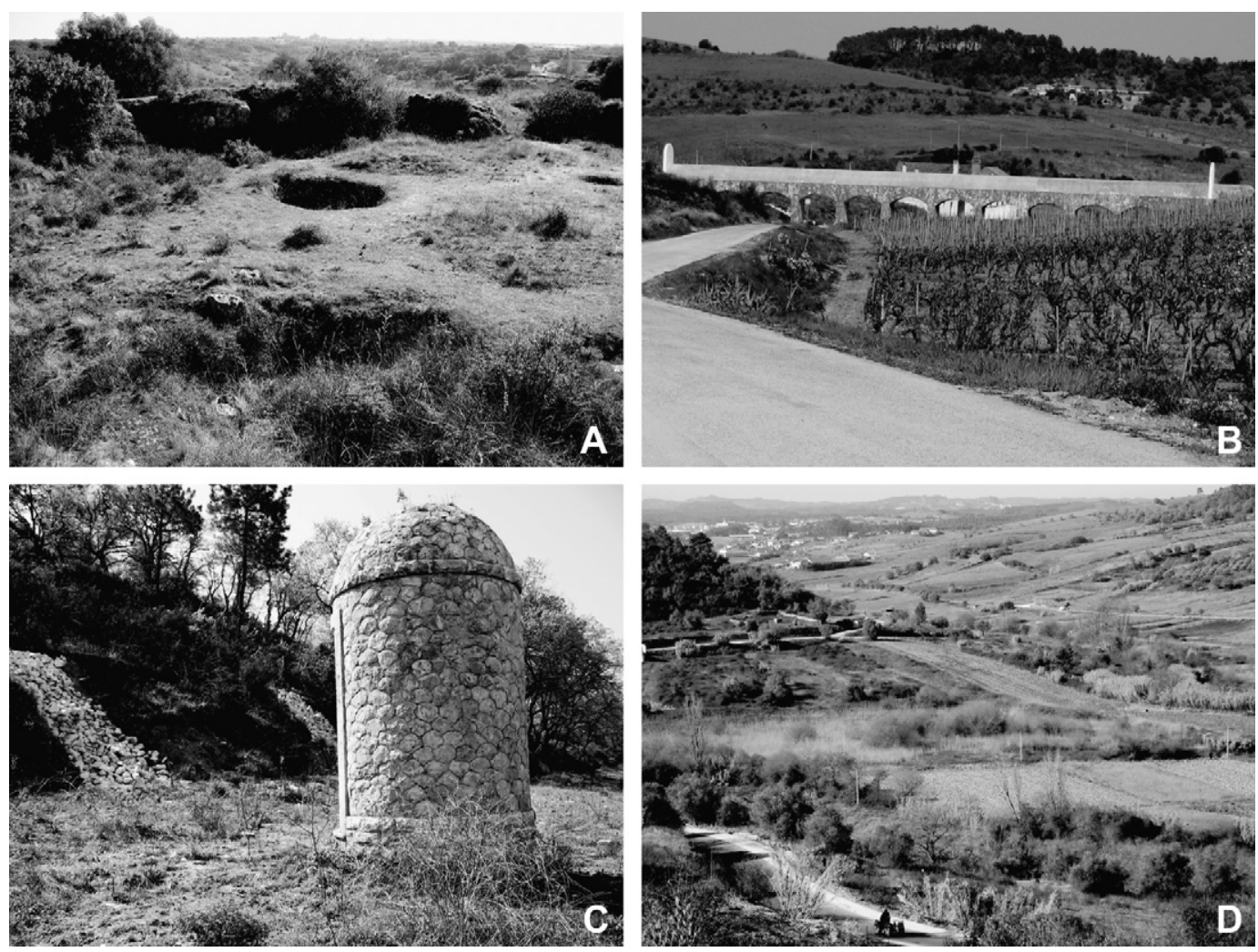

Fig. 8. Cultural patrimony: A - neolithic Castro; B - aqueduct; C - "houses of water" (morphology I); D - agricultural lands.

between 65 families and 210 genders were identified. The vegetation study was done using a GIS. According to best practice, (Lousã et al., 1996; Izco and Arco, 2003), the vegetation study dealt with the actual vegetation recorded on the ground, potential vegetation and potential habitats. This phase comprised the field collection of vegetal material, followed by the identification and interpretation of plant species in comparison with material from the João de Carvalho e Vasconcellos Herbarium (LISI-TULisbon).

The cultural landscape analysis utilized an inventory and historic records of the existing elements that represent human connections with landscape. The field work was also essential in order to observe, analyse and map those records, as it allowed an understanding of the present and past relationship between the inhabitants and the cultural elements of landscape.

The natural and cultural analysis lead to a diagnosis of the landscape and the recommendation of intervention and management measures (such as "intervention priority actions" and "habitat management") that can enhance landscape biophysical and scenic characteristics, in order to promote the equilibrium of ecosystems (the second phase of this methodology). Both the geomorphologic landscape dynamics and the slopes, for each area, were taken into account for the definition of intervention priorities. The proposed intervention measures for the landscape were divided into three essential areas: recovery (Class I), change of land use (Class II) and conservation (Class III). The main objective was to contribute to landscape equilibrium and, consequently, to the increase of landscape quality. Table 1 summarises the three priority classes.

The study of vegetation not only determines its state of conservation and main threats, but also supports the management measures for each habitat. With these measures, the primitive stages of serial vegetation continue to evolve and tree development is promoted. The recuperation and conservation of these habitats are decisive for proper landscape management.
An accurate diagnosis and a sustainable landscape proposal depend on a solid ecological interpretation. This facilitates the proposal and the designation of greenways, thus accomplishing the third phase of the described methodology. The routes will be designed relative to the existing roads and with the elements that were identified during the landscape eco-cultural analysis (heritage elements, panoramic views and habitats). These routes can be used for leisure as well as for environmental education. The proposal takes three main principles into account: comfort, continuity and scenic quality (pleasant views) of the ecological landscape.

\section{Results}

The results obtained are presented as follows, according to each specific step of the proposed methodology (Fig. 2) in order to achieve the greenway creation. The final result proposes a series of greenways within the study area (Fig. 10).

\subsection{Landscape eco-cultural analysis: biophysical analysis}

The main biophysical characteristics of the study area were identified in this first phase of "landscape eco-cultural analysis". This analysis also allowed an understanding of some of the limitations and/or fragilities that should be considered in landscape planning.

Four main interfluves, crowned by four plateaus, with an average altitude between 100 and $120 \mathrm{~m}$ were identified in the intervention area. The Almoster and Maçussa rivers are the main streams (Fig. 3A). Both rivers flow in valleys that are used for agricultural practices due to the highly productive soils (Fluvisols) developed on alluvium argillaceous Holocene formations. The other predominant soils include Cambisols and some Vertisols, both developed on Cenozoic formations, which date from Miocene to Pliocene (Zbyszewski, 1953; Zbyszewski et al., 1966). The plateaus (Fig. 3B) developed on limestone formations (Miocenic 

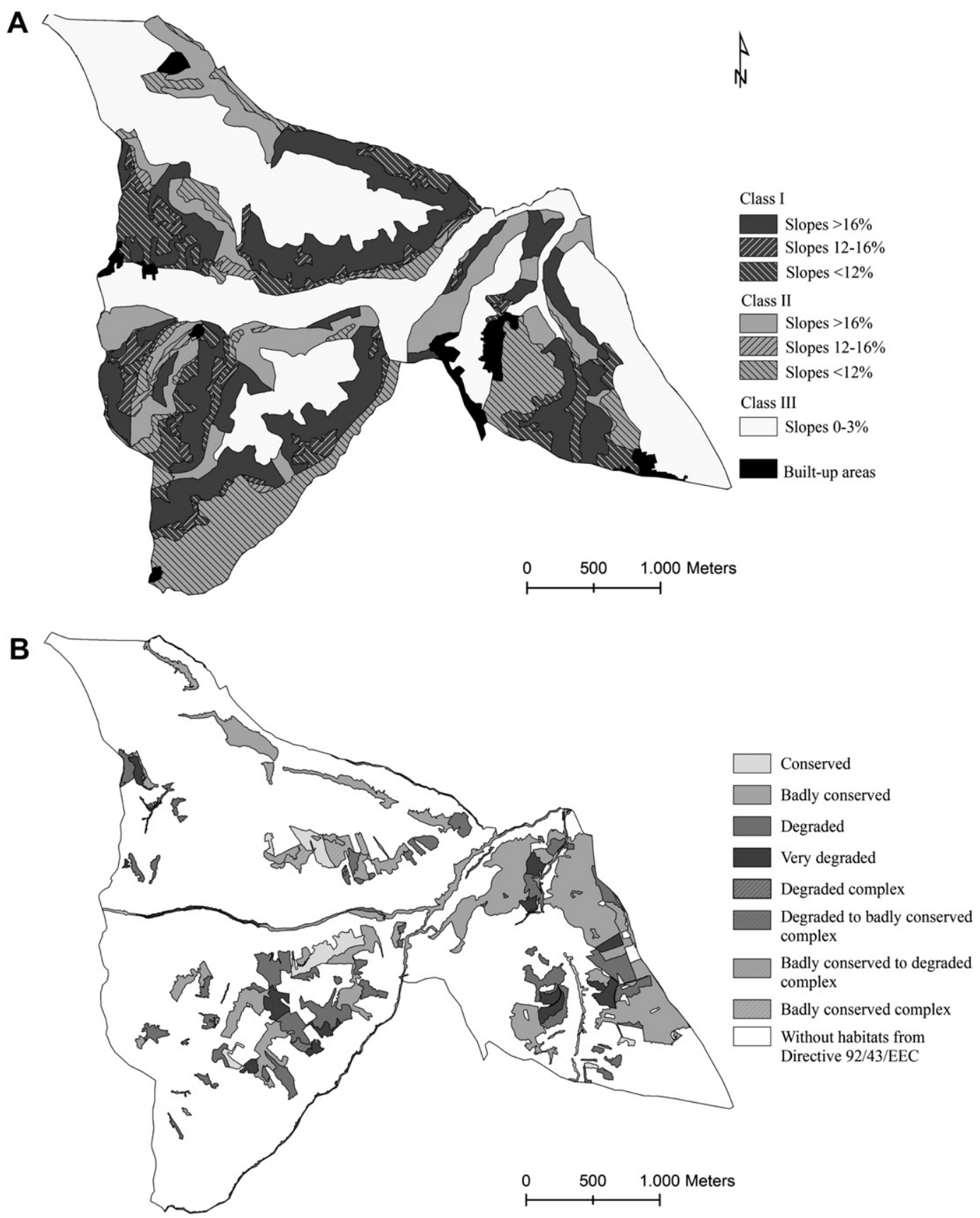

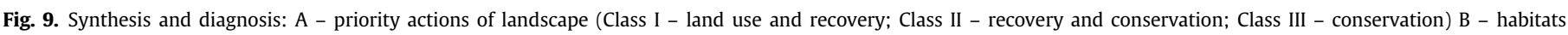
conservation state.

age) show an undulating relief and in some places, karstified areas (mainly lapies) were observed. Slopes are quite steep ( $>16 \%$ ), showing a concave-convex morphology in the Maçussa and Vale de Éguas valleys, a tendency to concavity north of the Almoster river, while the slopes located south of the same valley have a rectilinear morphology (Fig. 3B).

Sun exposure determines the bioclimatic comfort (south and west) for human activities (Fig. 4). The north slope of Almoster River shows a southern exposure and the left slope of the Maçussa and Vale de Éguas rivers show a western exposure. The bioclimate of the area is Mediterranean pluviseasonal-oceanic. Consequently, the study area presents an important biological diversity and a predominance of plants with Mediterranean characteristics, which were considered worth conserving.

\subsection{Landscape eco-cultural analysis: geomorphologic dynamic analysis}

Four geomorphologic classes were mapped (Fig. 5): pedogenesis, morphogenesis, intergrade to pedogenesis, and intergrade to morphogenesis. The values and characteristics of the different geomorphologic dynamics and the percentage of these dynamics in the area are presented in Table 2.

\subsection{Landscape eco-cultural analysis: vegetation analysis}

The vegetal original material of the study area consists of 78 phytosociological relevés, which were identified by the authors between March and August 2005 based on the concepts of 
Table 4

Management measures and threats for the identified habitats.

\begin{tabular}{|c|c|c|}
\hline Habitat & Threats & Management measures \\
\hline $\begin{array}{l}\text { 9240, 9330, 9340pt2 } \\
\text { (Fragments of woodlands) }\end{array}$ & $\begin{array}{l}\text { Wildfires } \\
\text { Excessive wood exploration } \\
\text { Wrong forestry planning }\end{array}$ & $\begin{array}{l}\text { Clear the accesses near the habitats without disturbing its boundaries, } \\
\text { considering the serial stages existing nearby } \\
\text { Promote dominant twigs in regenerating areas } \\
\text { Plant or seed mature stage species in areas with low regeneration levels } \\
\text { Create a plant/seed bank from local species } \\
\text { Promote the habitats values among local communities } \\
\text { Pruning should be developed in regenerating areas }\end{array}$ \\
\hline 92A0pt2 (Ripiculous galleries) & $\begin{array}{l}\text { Cutting down of dominant trees } \\
\text { Mechanized cleaning of riversides } \\
\text { Invasive species }\end{array}$ & $\begin{array}{l}\text { Constrain tree cuttings } \\
\text { Interdict mechanical cleaning with heavy machines in the habitat areas } \\
\text { Manual removal and cleaning of dead trees and raspberry bushes }\end{array}$ \\
\hline $\begin{array}{l}\text { 5330pt3, 5330pt4, 5330pt5 } \\
\text { (Chaparral) }\end{array}$ & $\begin{array}{l}\text { Wildfires } \\
\text { Habitats destruction }\end{array}$ & $\begin{array}{l}\text { Prevent wildfires } \\
\text { Control the thinning operations } \\
\text { Control the exploration of strawberry-tree fruits, compatible with habitats preservation } \\
\text { Promote the habitats values among local communities }\end{array}$ \\
\hline 6210 (Perennial grasslands) & $\begin{array}{l}\text { Small gap between fires } \\
\text { Tall scrubland expansion } \\
\text { Excessive grazing }\end{array}$ & Slowing down of the ecological succession process, encouraging the extensive grazing \\
\hline
\end{tabular}

phytosociological theory (Braun-Blanquet, 1979). The type of natural habitats and species to preserve were identified (Fig. 6A) according to annexes I, II and IV of the Directive 92/43/EEC (European Commission, 1992). The study of habitats is crucial to acquire knowledge of the territory and sustain the foreseeable correct management measures.

The potential vegetation (Fig. 6B) of the study region comprises three main series. The Asparago aphyllii-Querco suberis sigmetum is associated with the few siliceous rocks or valleys with pedological compensation. The Arisaro-Querco broteroi sigmetum is the Dividing Portuguese serial vegetation of Portuguese oak, occurs on decarbonated soils from limestone or marls and soils developed on calcarenites under a meso-Mediterranean climate, normally located at the bottom of the valleys and on slopes under oceanic influence. And also the Lonicero implexae-Querco rotundifoliae sigmetum, which is the Holm Oak serial vegetation, where soils are mostly dry for the majority of the year. The succession of this serial vegetation is summarised in Table 3.

The Riparian vegetation is associated with the forest that occurs in the Almoster stream valley: Typho angustifoliaePhragmitetum australis, Salici neotrichae-Populetum nigrae, Aro italici-Ulmetum minoris and Ficario ranunculoidis-Fraxinetum angustifoliae. Some communities in the study area were completely destroyed and replaced by cultivated fields; others are represented by small patches of riparian species reduced to narrow lines left by agricultural land use. These riparian forests are relatively frequent within the study site but show a significant level of disturbance.

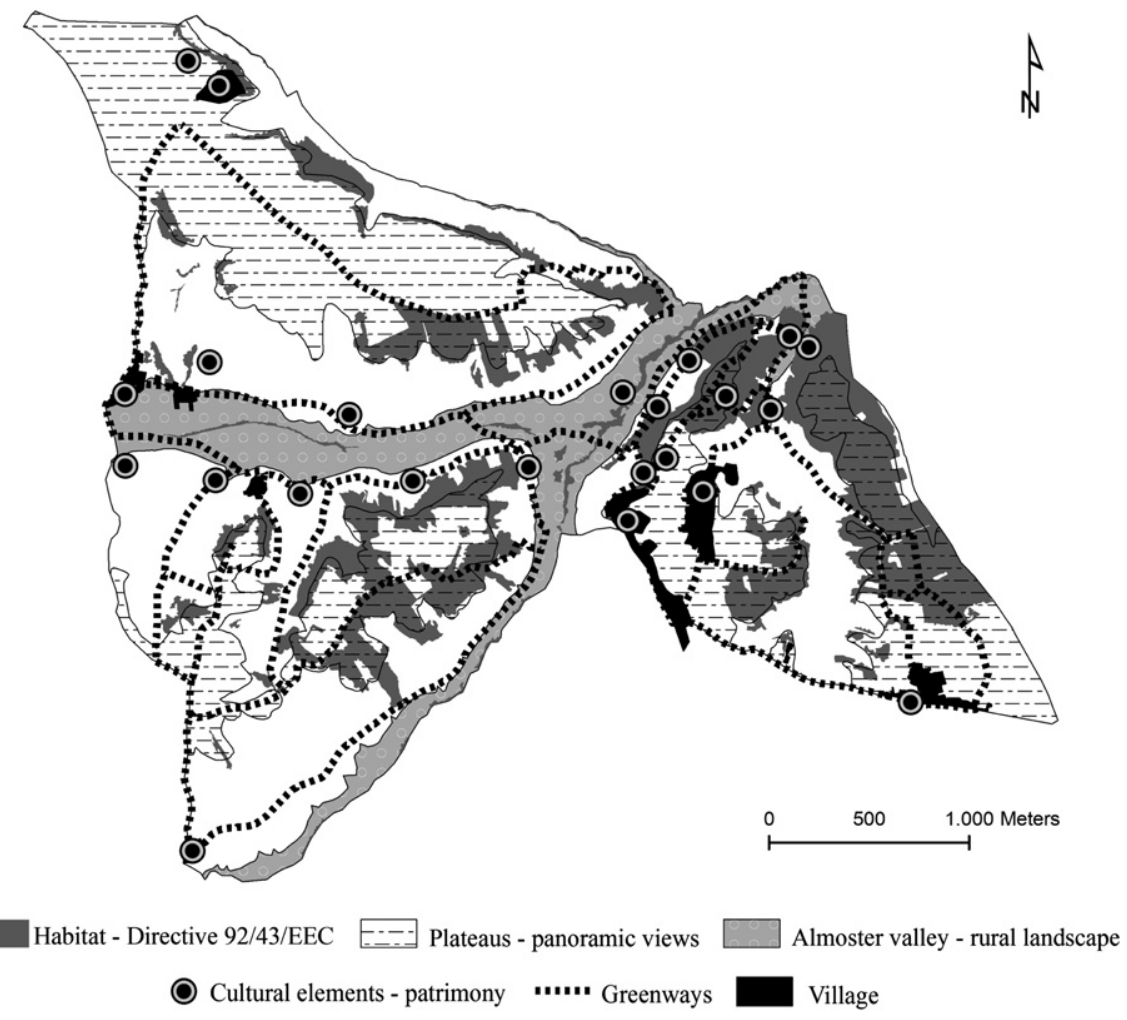

Fig. 10. Proposed greenways and the main landscape features to be considered in the landscape. 


\section{A}

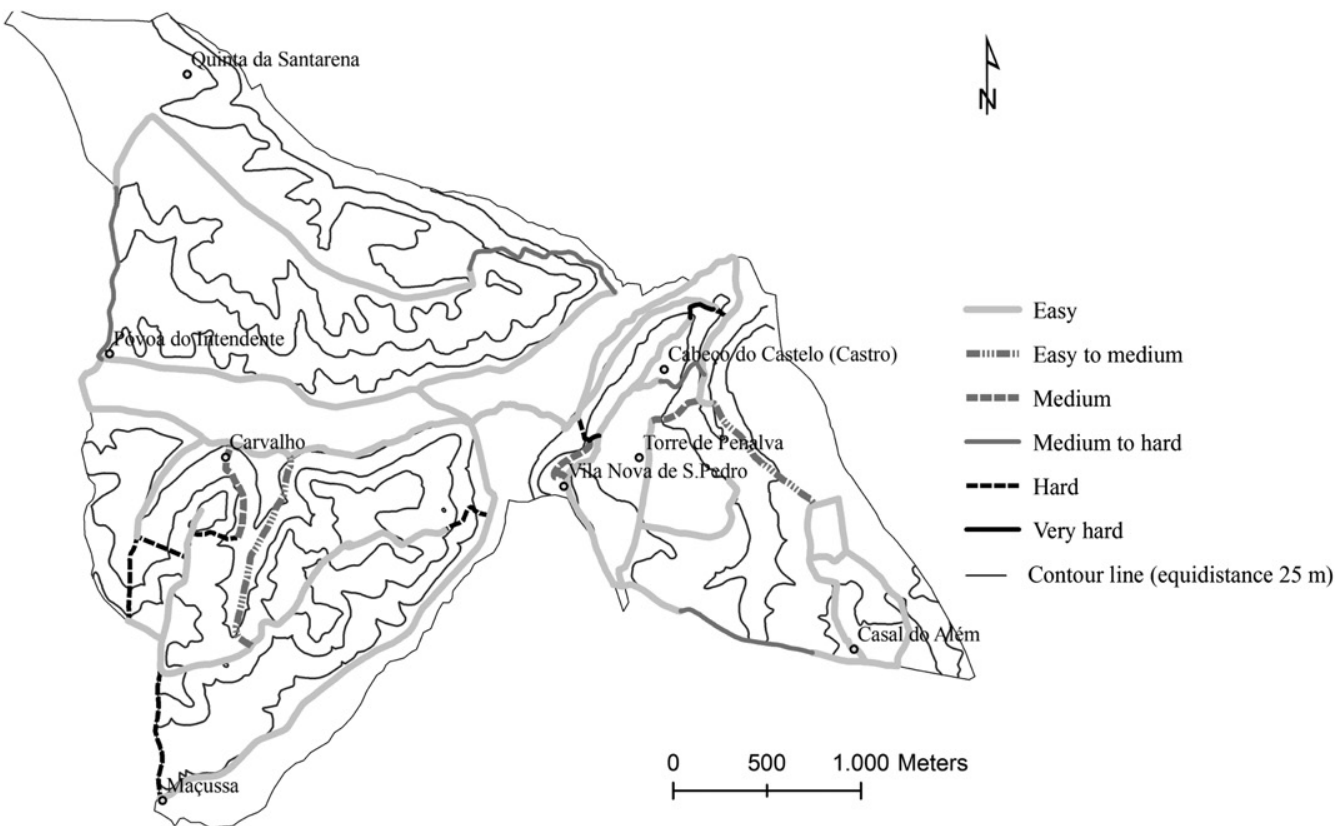

B

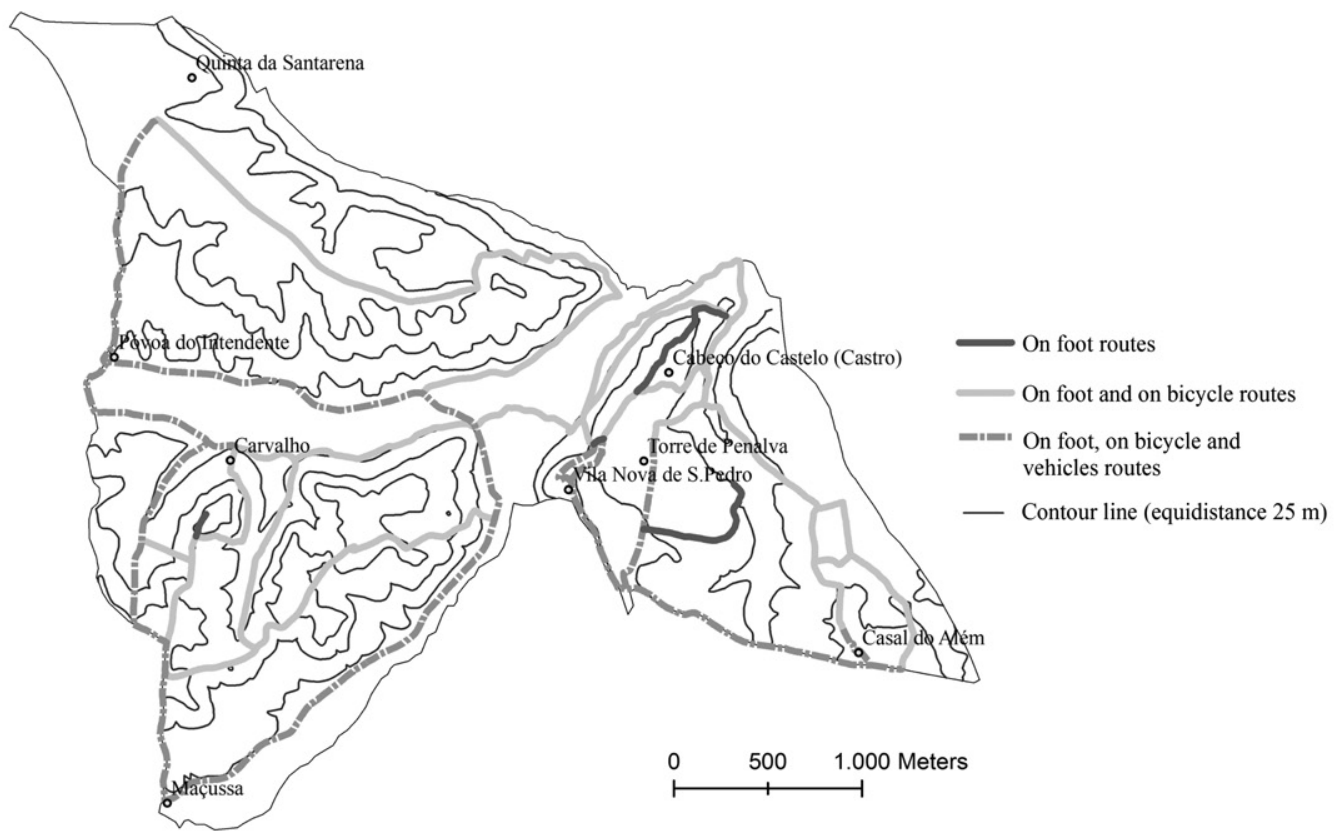

Fig. 11. Greenways: A - routes difficulty; B - different types of circulation.

\subsection{Landscape eco-cultural analysis: cultural analysis}

The landscape of the Almoster valley is dotted with heritage features of historical value and potential for development and integration with a network of routes (Fig. 7). The most relevant element is the Castro (Fig. 8A) dating back to Neolithic times (1000-5000 BC). This structure is made up of three circles of stone walls and is an archaeological site which has evidence of human activity from Neolithic times. Due to considerable degradation, urgent restoration and subsequent conservation are required. Apart from its prehistoric value, the area also has considerable scenic value, as the Castro site provides views to several natural elements. The main viewpoints in the study area are located on the plateaus (100-120 m altitude), identified in the geomorphology map (Fig. 3B). The plateaus provide panoramic views of the natural and cultural features of Montejunto Mountain, and of the Almoster valley. The scenic landscape quality is also improved by the high value of the Habitats from the Directive 92/43/ECC identified in the vegetation analysis of the study area (Fig. 6A).

The study area is crossed by a $120 \mathrm{~km}$ long pipeline (known as Cano do Alviela) that conveys water from the Spring of the Alviela River to Lisbon. This gravity flow pipeline was built in 1880 to supply Lisbon with water and is still in operation today. Some patrimonial structures are located along the Alviela pipeline which help to create a particular character to this landscape. These structures include the pipeline sections (Fig. 8B) and the so called "casas da água" ("houses of water") (Fig. 8C). Those "houses of water" are shown on two different architectures but with the same access functions to the Alviela aqueduct. 
Table 5

Length of the routes and time spent by the user on foot or on bicycle.

\begin{tabular}{llll}
\hline Route/section & $\begin{array}{l}\text { Length } \\
(\mathrm{km})\end{array}$ & $\begin{array}{l}\text { Time spent } \\
\text { (minutes) in } \\
\text { the route on } \\
\text { foot (medium } \\
\text { speed: } 5 \mathrm{~km} / \mathrm{h})\end{array}$ & $\begin{array}{l}\text { Time spent } \\
\text { (minutes) in } \\
\text { the route on } \\
\text { bicycle }(\text { medium } \\
\text { speed: } 10 \mathrm{~km} / \mathrm{h})\end{array}$ \\
\hline $1-(25)-(10)-(23)-(6)-2$ & 3.90 & 47 & 24 \\
$3-4$ & 4.58 & 55 & 28 \\
$5-(18)-(20)-(2)-6$ & 2.21 & 27 & 14 \\
$2-(19)-7$ & 1.36 & 16 & 8 \\
$8-(12)-9$ & 3.26 & 39 & 20 \\
$9-(11)-(24)-(27)-(28)-10$ & 2.27 & 27 & 14 \\
$11-(22)-12$ & 2.23 & 27 & 14 \\
$6-(7)-(14)-(17)-13$ & 2.76 & 33 & 17 \\
$5-(15)-14$ & 0.92 & 11 & 6 \\
$15-16$ & 0.78 & 9 & 5 \\
$17-(21)-18$ & 1.87 & 22 & 3 \\
$19-20$ & 0.51 & 6 & 7 \\
$13-21$ & 1.19 & 14 & 7 \\
$22-23$ & 1.11 & 13 & 8 \\
$24-(26)-25$ & 1.32 & 16 & 20 \\
$1-(3)-(8)-4$ & 3.30 & 40 & 1 \\
$26-27$ & 0.30 & 4 & 2 \\
$28-29$ & 0.13 & 2 & \\
\hline
\end{tabular}

The cultural landscape also includes some former rural houses, as well as two bridges, which are possibly of Roman origin and located in the Vale de Éguas and in the Almoster streams. A public open air laundry house was also considered as a notable heritage feature due to its rarity nowadays and because it can be restored for environmental education purposes.

The agricultural lands bordered by hedges are part of the rural heritage of the area. These lands are located in areas where soils have a high ecological value in the large Almoster (Fig. 8D) and Vale de Éguas valleys. The ancient stone walls built with the local hard stone (limestone and calcarenite) must also be classified as rural heritage as they represent a history of a plentiful and cheap labour force. They are also indicators of technology and methods of construction in a particular time and place. These walls are still very important structures reducing the instability of some slopes and are in urgent need of recovery and conservation work.

\subsection{Synthesis and diagnosis: intervention priority actions}

The actions for intervention priorities in the studied area were organized in three classes and are illustrated in Fig. 9A. The measures for the three proposed classes should be taken to promote ecological stability. By doing so, it is possible to improve water and soil conservation and soil quality in order to develop agriculture and minimise potential hazards, such as landslides.

The areas classified as Class I and with slopes between 12 and $16 \%$ (highly destabilised areas) should be planted with intense vegetation cover with species of locally native flora, which must include three strata of species (arboreal, shrubby and herbaceous). On agricultural terrain, cultivation should be by terrace and contour ploughing with minimum tillage. In the non-cultivated areas, which is due to agricultural abandonment or crop rotation, the land should be covered by vegetation using permanent or temporary grassland or even forests or permanent bushes. The main goals of these intervention measures are soil and water conservation. In areas with slope $>16 \%$ (Class I), vegetation cover exclusively by autochthonous species is recommended, as these areas are more exposed to several erosion processes.

Measures suggested for Class II areas are mostly focused on recovering the existent vegetation. They include the planting of species adapted to the climatic and soil conditions of the area and changes to land use, in order to minimise erosion processes. This is particularly significant in the areas with slopes $>16 \%$ especially if built up on sedimentary strata with different physical behaviour. such as marls, clays and limestone rocks.

Areas classified as Class III were already stable; therefore, it is necessary to maintain the present agricultural practices and/or the actual land use, as these areas show no signs of landscape degradation. In the study site, the well vegetated summits and riverbanks correctly protected with the appropriate vegetation are examples of stabilised areas. Also the correct landscape compartmentalisation by hedges, as observed in the adjacent areas of the riversides of Almoster and Maçussa, are examples of well stabilised areas. Consequently, in the areas classified as Class III the actual land use is correct and must be encouraged.

\subsection{Synthesis and diagnosis: interventions habitat management}

The interpretation of the habitats (Fig. 6B) and their degree of conservation gave rise to the habitats conservation map (Fig. 9B). It was noted that the woodlands are few in number and poorly conserved, but the chaparral and scrublands are very well preserved. In order to improve the former and to protect the latter, some management measures are advised as noted in Table 4 according to Habitats threats. Some of the advised measures include: clearing the accesses near the habitats without disturbing its boundaries; promote the dominant sprouting in regenerating areas; creating a plant/seed bank from local species; promoting the value of the variety of habitats amongst local communities; forbidding mechanical cleaning with heavy machinary in the habitat areas; and the preventing wildfires.

\subsection{The proposal}

Once the priority actions and the management measures for habitats that ensure the ecological equilibrium of landscape have been implemented, it is then possible to propose sustainable greenways.

The greenways and the relevant elements in the studied landscape are shown in Fig. 10, and they are the result of the biophysical, geomorphologic, vegetation and cultural analysis. However, it is necessary to use the existing routes and roads in order to minimise any environmental and cultural landscape impacts. Therefore, the green routes were designed considering the ease of accessibility to the existing ways (roads, rural tracks, paths, etc.) and the comfort of users. These routes were then planned, taking into account the slopes, and classified according to their degree of difficulty (Fig. 11A).

The evaluation of the current circulation allows, in a first analysis, to understand which type of use (pedestrian, bicycle and/or motor vehicles) is more appropriate for each route (Fig. 11B). However, safety considerations are necessary to prevent conflicts between different types of users. The use of cars and cyclists/ pedestrians should be made compatible through measures that promote aesthetic quality and user safety. For this reason, the following measures should be included in the initial project stage: the separation of pedestrian paths, use of vegetation as a barrier to separate traffic and using varying types of paving.

According to the European Commission (2000) publication regarding bicycles, time estimations were made for travelling over the different route sections by bike and on foot (Table 5 and Fig. 12A).

The routes were classified, according to their landscape characteristics and the environmental and scenic potential of the area. Four different itineraries were created (Fig. 12B, Table 6): Plateau, 
A

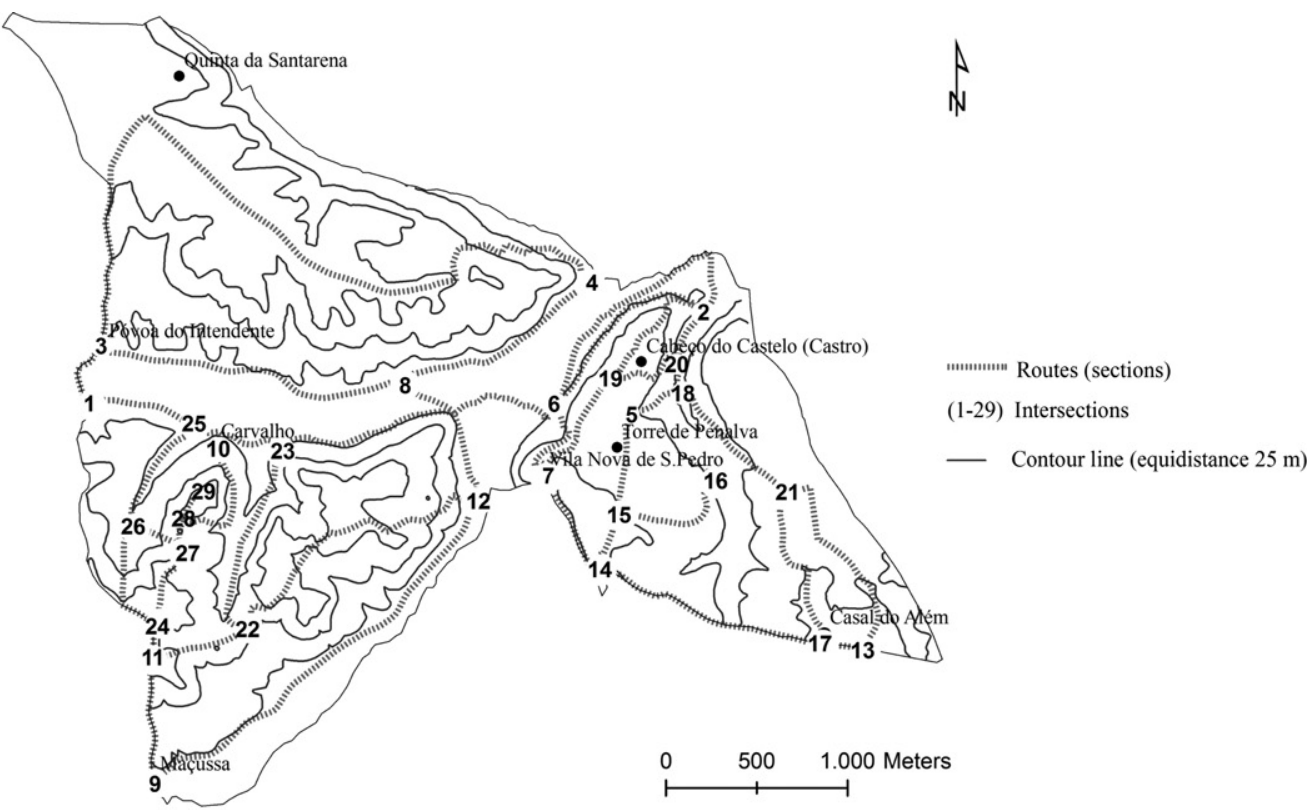

B

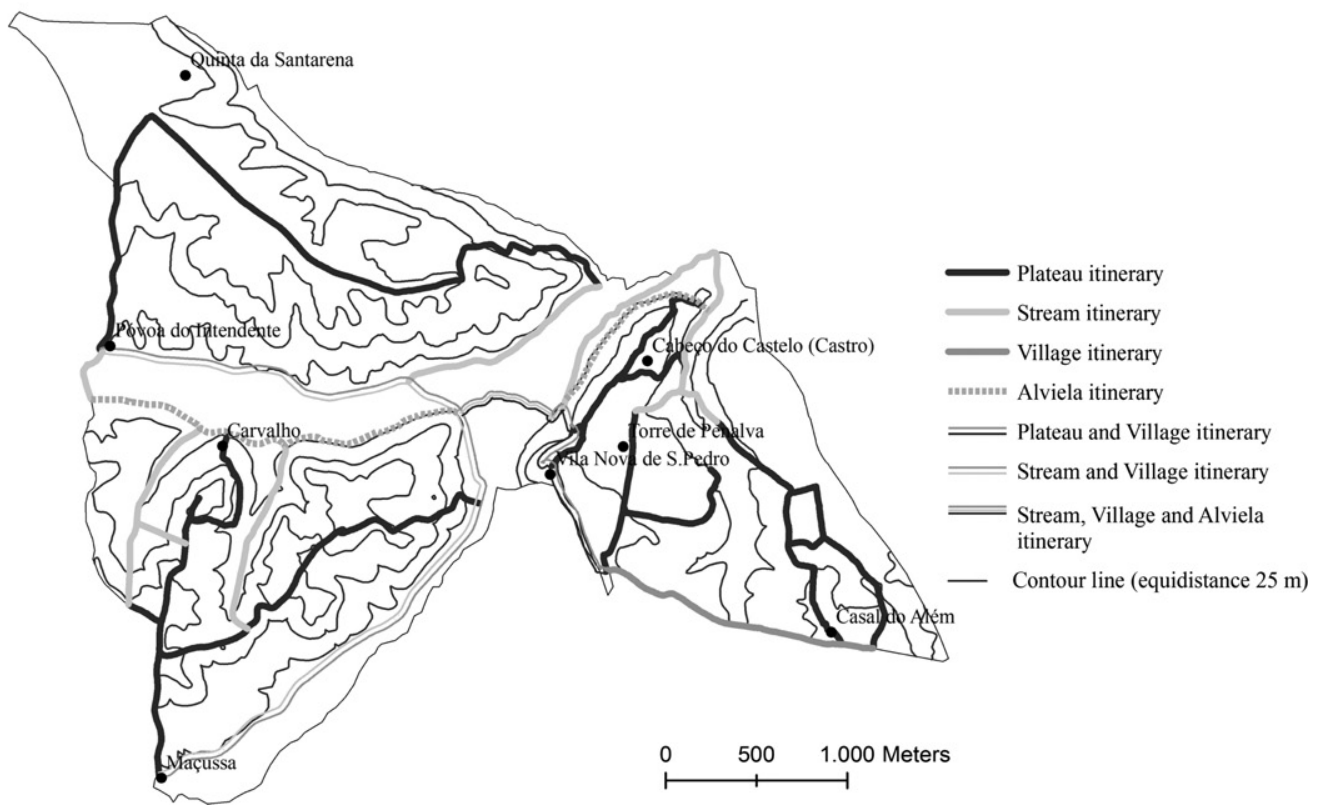

Fig. 12. Greenways: A - routes and route intersections; B - typology of greenways itineraries.

Stream, Village and Alviela. Itineraries with a mixed classification of the former ones were also considered: (1) Plateau and Village, (2) Stream and Village, and (3) Stream, Village and Alviela.

\section{Discussion}

The concept of interaction between leisure, ecology and economy only appeared in Portugal in the last decade (Cabinet Resolution $\left.n^{\circ} 112 / 98\right)$. However, there's a strong commitment to developing nature activities, such as hiking, climbing, caving and bicycle riding. In all of these activities, contact with the local population is encouraged through gastronomy, ethnography and lodgings in traditional housing. To ensure these interactions between environment, society and economy it is important to guarantee landscape connectivity. According to the studies developed by Ribeiro and Lovett (2009), the landscape connectivity will assure provision environment goods and services. Greenway planning includes this landscape connectivity principle.

The study carried out on the Almoster area has illustrated that the comprehensive analysis of landscape, which includes ecological, cultural and physical factors, is important when proposing greenways. The understanding of the main landscape characteristics and features includes its fragilities, landscape processes, cultural identity and the scenic and educational potential.

One of the key factors for maintaining a sustainable ecosystem is the preservation of natural spaces (Levin et al., 2007). This principle is achieved in this study because the proposed greenways have a minimal effect on the landscape. In addition, the proposed methodology includes a planned landscape intervention that considers the recovery of degraded areas, erosion decrease and reestablishing the native ecology, in order to achieve landscape sustainability. This sustainable landscape plan will improve 
Table 6

Itineraries main characteristics.

\begin{tabular}{ll}
\hline Itinerary & Characteristics \\
\hline Plateau itinerary & $\begin{array}{l}\text { Most expansive scenic views } \\
\text { Places for leisure } \\
\text { Environmental interpretation } \\
\text { Cultural interpretation (Castro) }\end{array}$ \\
& $\begin{array}{l}\text { Along rivers } \\
\text { Environmental interpretation } \\
\text { Stream itinerary }\end{array}$ \\
& $\begin{array}{l}\text { Connection among the villages } \\
\text { Village itinerary }\end{array}$ \\
Alviela itinerary & $\begin{array}{l}\text { Along the Alviela pipeline } \\
\text { Observation of cultural patrimony } \\
\text { ("houses of the water" and the aqueducts) } \\
\text { Valley views }\end{array}$ \\
\hline
\end{tabular}

landscape quality (scenic and ecological) and consequently boost the potential for greenways to be used by people.

It is considered important to have a management plan that includes the followed general actions: recovery measures, conservation measures and habitat management measures. The first measures ensure geomorphological stability. These are summarised in Table 1 . The habitat management measures guarantee the good evolution of the habitats (Table 4), and consequently the achievement of biodiversity, one of the four priority areas of the sixth EU Environmental Action Programme (European Commission, 2004) and a key factor for landscape sustainability and management (Mörtberg et al., 2007; Jaeger et al., 2008).

For greenways planning, with a strong environmental component for nature tourism, education and culture, the factors required are as follows:

- the landscape elements and characteristics must be highlighted;

- the unstable areas should be recovered;

- the cultural elements should be integrated as they make the connection between users and inhabitants. Cultural elements represent the past and the current memory of landscape.

All the abovementioned principles were considered for the itineraries proposed for the studied area.

The rural greenway planning and the proximity to a city centre also give rise to a group of associated opportunities:

- the implementation of the environmental proposal for the region can help the socio-economic problems of the rural population;

- greenways can be an opportunity to involve local communities through their direct participation and trade of local goods (wine, cheese, honey, vegetables, etc.), as well as traditional handcraft. This trade can make a significant contribution to the development of the local rural economy;

- the fact that the area is located relatively close to Lisbon means that a large population can have access to the greenway system with its important health and cultural benefits.

According to the studies developed by Ahern (1995), greenways must also include social and cultural goals, not only those of environment protection. Termorshuizen et al. (2007) state that decisions regarding landscape should have three dimensions: ecophysical, social (human perception and health) and economic (capacity to produce economic values). The three proposed dimensions derive from the principles of sustainable development, in which ecological, social and economical functions are balanced in time and space to maintain their potential for future generations (WCED, 1987). In this study, these three defined principles are respected and integrated as part of the methodology. However, the main weakness of the presented methodology is the implementation time. If all ecological measures were implemented, the social benefits would be faster than the economic ones, as the latter involve political will and the cooperation of the local population.

In the future, greenways should be designed in a more detailed way. The project scope should include information such as orientation signs, indicating the length and time for every itinerary, landscape panels with the location and a summary description of the habitats, geology/geomorphology and cultural aspects, interpretation centre, furniture and a car park. These types of project should be carried out by the municipality, local commerce, nature groups and local volunteer associations in such a way that it encourages local inhabitants to participate in their planning, design, as well as maintenance and management.

\section{Summary and conclusion}

This study has used a particular enclave, but for it to be developed successfully it needs to be integrated with similar studies within its boundaries and beyond. However, within this study it is possible to produce some final considerations. These are as follows:

1. the study of the ecological and cultural context of a landscape is essential to achieve sustainable planning, which is the basis of the greenways proposal;

2. field work facilitates the understanding of ecological and human dynamics;

3. an interdisciplinary approach is essential where the interactive elements of the landscape systems (and sub-systems) are understood and discussed;

4. it is also essential to encourage the dynamic geomorphological stabilization, so that a balanced landscape can be enjoyed.

A balanced landscape will increase the value of the greenways and in return, the routes can develop activities, such as nature tourism, environmental education that will promote landscape sustainability and stimulate social, economic and ecological dynamics.

The methods and processes undertaken in this study indicate that the considered and holistic design of greenways can help to improve landscape conditions and contribute to sustainable landscape planning and generally encourage more sustainable development, with concomitant economic, social and environmental benefits. As in the case study, the economic, social and environmental benefits can be reached with this methodology.

\section{Acknowledgements}

The authors would like to thank the Azambuja Municipality, for their financial support with special thanks to Eng. Ana Farinha (Environment Division) for her support during the development of this project.

\section{References}

Ahern, J., 1995. Greenways as a planning strategy. Landscape and Urban Planning 33, 131-155.

Ahern, J., 2005. Theories, methods and strategies for sustainable landscape planning. Available from: http://people.umass.edu/jfa/pdf/SLP.pdf.

Braun-Blanquet, J., 1979. Fitosociologia - Bases para el estudio de las comunidades vegetales, third ed. $\mathrm{H}$ Blume Ediciones, Madrid.

Cabinet Resolution $\mathrm{n}^{\circ}$. 112/98, 25th August 1998. http//www.diramb.gov.pt/data/ basedoc/TXT_LN_18829_1_0001.htm. (accessed 1005 05).

Chadwick, G.F., 1978. A Systems View of Planning, second ed. Pergamon Press. 
Christofoletti, A., 1999. Modelagem de Sistemas Ambientais. Editora Edgard Blücher. Cloquell-Ballester, V.-A., Monterde-Díaz, R., Cloquell-Ballester, V.-A., TorresSibille, A.C., 2008. Environmental education for small- and medium-sized enterprises: methodology and e-learning experience in the Valencian region. Journal of Environmental Management 87, 507-520.

Council of Europe, 2000. European landscape convention. http://conventions.coe. int/Treaty/en/Treaties/Html/176.htm (accessed December 2005).

Cole, D.N., Landres, P.B., 1996. Threats to wilderness ecosystems: impacts and research needs. Ecological Applications 6, 168-184.

Demir, M., Hasdemir, M., 2005. Functional planning criterion of forest road network systems according to recent forestry development and suggestion in Turkey. American Journal of Environmental Sciences 1, 22-28.

Demir, M., 2007. Impacts, management and functional planning criterion of forest road network system in Turkey. Transportation Research Part A 41, 56-68.

European Commission, 1992. Habitats directive 92/43/EEC. http://ec.europa.eu/ environment/nature/nature_conservation/eu_nature_legislation/habitats directive/index_en.htm (accessed November 2005).

European Commission, 2000. Cidades para Bicicletas, Cidades de Futuro. http://ec. europa.eu/environment/cycling/cycling_pt.pdf (accessed Decenber 2005).

European Commission, 2004. The sixth environment action Programme of the European Community 2002-2012. Available from: http://eurlex.europa.eu/ LexUriServ/LexUriServ.do?uri=CELEX:52001DC0031:EN:HTML.

Goodchild, P., 2002. Paisagem e Património. Associação Portuguesa de Arquitectura Paisagista 3, 6-8.

Izco, J., Arco, M., 2003. Código Internacional de Nomenclatura Fitosociológica. Materiales didácticos universitários, Botânica 2. Universidad de la Laguna, Santa Cruz de Tenerife.

IHERA (Instituto de hidráulica, Engenharia Rural e Ambiente), 1970. Cartas de Solos n. ${ }^{\circ} 351,352,363,364$. Escala [1/25000].

Jaarsma, F. C., 1994. Rural Low-traffic Roads (LTRs): the Challenge for Improvement of Traffic Safety for All Road Users. In: 27th ISATA, Dedicated Conference on Road and Vehicle Safety, Aachen, Germany, pp. 177-183.

Jaarsma, F.C., 1997. Approaches for the planning of rural road network according to sustainable land use planning. Landscape and Urban Planning 39, 47-54.

Jaarsma, F. C. and van Langevelde, F., 1996. The Motor Vehicle and the Environment: Balancing between Accessibility and Habitat Fragmentation. In: 29th ISATA, Dedicated Conference on the Motor Vehicle and the Environment, Florence, Italy, pp. 299-306.

Jaeger, J.A.G., Bertiller, R., Schwick, C., Müller, K., SteinmeierEwald, K.C., Ghazoul, J. 2008. Implementing landscape fragmentation as an indicator in the Swiss monitoring system of sustainable development (Monet). Journal of Environmental Management 88, 737-751.

Korhonen, J., 2007. Environmental planning vs. systems analysis: four perspective principles vs. four descriptive indicators. Journal of Environmental Management 82, 51-59.

Levin, N., Lahav, H., Ramon, U., Heller, A., Nizry, G., Tsoar, A., Sagi, Y., 2007. Landscape continuity analysis: a new approach to conservation planning in Israel. Landscape and Urban Planning 79, 53-64.
Lousã, M., Espírito-Santo, M.D., Costa, J.C., 1996. A vegetação da Serra de Alvaiázere. Anais Instituto Superior de Agronomia 44, 215-233.

Magalhães, M.R., 2001. A Arquitectura Paisagista, morfologia e complexidade. Editorial Estampa, Lisboa.

Magalhães, M.R., Abreu, M.M., Campo, S.L., Cunha, N.S., Silva, P.G., 2003. The local ecological structure as a tool of landscape sustainability. The case study of Loures (Portugal). In: Proceedings of the 4th European Congress on Regional Geoscientific Cartography and Information Systems. Geoscientific Information for Spacial Planning, Bologna, Italy, pp. 75-77.

Magalhães, M.R., Abreu, M.M., Lousã, M., Cortez, N., 2007. Estrutura Ecológica da Paisagem. Conceitos e Delimitação - escalas regional e municipal. IsaPress, Lisboa, Portugal.

McHarg, I., 1971. Design with Nature. NHP, New York.

Mörtberg, U.M., Balfors, B., Knol, W.C., 2007. Landscape ecological assessment: a tool for integrating biodiversity issues in strategic environmental assessment and planning. Journal of Environmental Management 82, 457-470.

Parkin, J., Wardman, M., Page, M., 2007. Models of perceived cycling risk and route acceptability. Accident Analysis and Prevention 39, 364-371.

Ribeiro, S.C., Lovett, A., 2009. Associations between forest characteristics and socioeconomic development: a case study from Portugal. Journal of Environmental Management 90, 2873-2881.

Ritchie, B.W., 1998. Bicycle tourism in the South Island of New Zealand: planning management issues. Tourism Management 19, 567-582.

Rivas-Martínez, S., 2005. Avances en Geobotánica. Discurso de Apertura del Curso Académico de la Real Academia Nacional de Farmácia del año 2005. Available from: http://www.ucm.es/info/cif/book/ranf2005.pdf.

Sauer, C.O., 1925. The morphology of landscape. Geography 2, 19-53.

Stephenson, J., 2008. The cultural values model: an integrated approach to values in landscapes. Landscape and Urban Planning 84, 127-139.

Telles, G.R., 1992. A conservação das Paisagens Históricas e Rurais. Correio da Natureza 17, 53-55.

Termorshuizen, J.W., Opdam, P., Brink, A.V.D., 2007. Incorporating ecological sustainability into landscape planning. Landscape and Urban Planning 79, 374-384.

Tricart, J., 1965. Morphogènese et pédogenèse, géomorphologie et pédologie. Science du Sol 1, 69-85.

Tricart, J., 1994. Écogeographie des Espaces Ruraux. Nathan, Paris.

Toccolini, A., Fumagalli, N., Senes, G., 2006. Greenway planning in Italy: the Lambra river valley greenways system. Landscape and Urban Planning 76, 98-111.

Williams, T., January to February 1998. The Unkindest Cuts. Audubon, pp. 24-31.

WCEDWorld Comission on Environment and Development, 1987. Our Commom Future. Oxford University Press, Oxford and New York.

Young, 1992. Nature tourism in Northwest Pennsylvania. Available from: http:// naturetourism.allegheny.edu/.

Zbyszewski, G., 1953. Carta Geológica de Portugal na escala 1/50000, Notícia Explicativa da folha 31-A Santarém. Serviços Geológicos de Portugal, Lisboa.

Zbyszewski, G., Ferreira, O.V., Manuppella, C.T.A., 1966. Carta Geológica de Portugal na escala 1/50000, Notícia Explicativa da folha 30-B Bombarral. Serviços Geológicos de Portugal, Lisboa. 